\title{
The determination of cooperative teacher's knowledge problems: training device and attractiveness of Tunisian student-teachers
}

\author{
Zayed W. ${ }^{1 \mathrm{ABCD}}$, Zguira M.S. ${ }^{2 \mathrm{AD}}$, Souissi N. ${ }^{3 \mathrm{AD}}$, Bali N. ${ }^{4 \mathrm{ABD}}$ \\ ${ }^{1,2}$ High Institute of Sport and Physical Education, University of Gafsa, Gafsa, Tunisia \\ ${ }^{3,4}$ High Institute of Sport and Physical Education, University of Manouba, Manouba, Tunisia \\ ${ }^{1,4}$ Laboratory Sport Performance Optimization, Tunis, Tunisia
}

Authors' Contribution: A - Study design; B - Data collection; C - Statistical analysis; D - Manuscript Preparation; E - Funds Collection.

\begin{abstract}
Purpose: $\quad$ This study was to explore the impact of the cooperative teacher's (CT) knowledge on attractiveness of Physical Education Student Teachers (PE-ST) believed to be important for a successful process of learning to teach and training device in the workplace. The $\mathrm{CT}$ is considered, a key element, a person of alternation between academia and training contributing to the formation by advice and support that take place during the teaching practice. The Cooperative Teacher must have a style; develop a training contract, master interview techniques and make evaluation.

Material: $\quad$ Data were collected with 302 student teachers (202 males and 100 females) after professional training. A descriptive/exploratory methodology based on a questionnaire consisting of twenty questions was used. The value of Cronbach alpha index is 0.729 .

Results: Globally supported the hypotheses. Male and female student teachers in the internship shared several perceptions. However, significant differences emerged. Student-teachers' perception of CT knowledge and practice developed relatively professional skills as well as the feeling of discomfort which can lead to work stoppage. However, the impact of CT knowledge on attractiveness was significant. The inefficiency advice between actors in the professional life and several aspects of CT knowledge are provided. In addition, data are provided indicating that overall there are more similarities than differences between male and female student teachers over a response number. Data also shows that females who participate in the internship may be at risk for discomfort, incapability and doubt their practices.
\end{abstract}

Conclusions: This study will encourage Teacher's to reflect on their own knowledge, training device and to include them in the process of educational development.

Keywords: professional training, teaching practice, knowledge, discomfort.

\section{Introduction}

Studies of the process of becoming a teacher and professional skills development have received significant attention in the last decade, trying to explain the complexities of this phenomenon. However, questions remain as to how well higher education institutions prepare the Student Teachers (PE-STs) to meet the challenges and requirement of work environments. Thus, professionals know how to put their skills into action in all situations, able to think in action and to adapt and dominate any new situation [1, 2, 3]. Though, skills are deployed in a professional context $[4,5,6]$. Tardif [7] claimed that the internship is the foundation of the professional skills of the teachers; it is the opportunity to put pedagogical, didactic and disciplinary knowledge for learning professional practice. In addition, the process of learning to teach develops self and class understanding and enriches teaching practices and professional thinking [8]. In this context, Brawdy \& Byram [9] suggest that future teachers should be given the opportunity to acquire appropriate teaching skills and develop the practical experience of teaching in schools. Teaching skills are rooted in the personal history of teachers, and can only be learned through practice [10]. According to Desbiens et al. [11] the internship is alternating and continuous with

\footnotetext{
(c) Zayed W., Zguira M.S., Souissi N., Bali N., 2019

doi:10.15561/20755279.2019.0208
}

other training times. It is the training time that promotes a familiarization with the dynamics of school and class, and the construction of professional action.

In the workplace, the cooperative Teacher (CT) is considered a person of alternation between academia and training, contributing to the formation by advice and support [12, 13]. This support requires experience and skills in terms of accompaniment such as knowing how to communicate, reflect on its action, observe, solve problems and evaluate the trainees' learning [14]. This is corroborated by a number of studies in different disciplines. For instance, Boutet \& Rousseau [15] opined that the characteristics of an effective CT are: experience, self-confidence, openness to theoretical contributions and reflection, coherence and acceptance to be questioned. Carlier [16] assumed that the CT and PE-ST exchange academic and practical knowledge to guide the verbalization of PE-ST's action by asking questions that they have put in place. He suggests that CTs recognize the existence of two types of knowledge and try to exploit them optimally. The aim is to train an independent teacher with specific, specialized skills based on rational, recognized, science-based knowledge, legitimized by the University or explicit knowledge derived from practices $[1,17]$.

Vandercleyen et al. [18] highlight the dual role of CT, to be able to explain their own pedagogical concepts to 
PE-ST and help them to clarify their thoughts, actions and decisions. However, Chaliès \& Durand [19] note that internship experiences have unclear objectives, poorly framed theoretically, lack planning and supervision by host communities. The internship may lose sight of the educational and social goals pursued. Concerns maintain that (PE-STs) The accompaniment practices may not be equipping (PE-STs) with the key skills needed to confront real teaching problems $[20,21,22]$. This experience may become a source of discomfort and confusion [23, 24]. Ndoreraho \& Martineau [25] report that stress in work environment affect the interest of PE-ST in the teaching profession. Brau-Antony et al. [26] found that tutoring is a difficult function to perform because the skills required to be a tutor are different from teaching. On another hand, the higher education institutions should develop the criteria for selecting CTs [27, 28, 29].

In Tunisia, university aim is to help PE-STs articulate the process of teaching learning in schools. We answered through this research the following questions are: the knowledge of the CT transformed in to discomfort? What impact do they have PE-STs?

\section{Materials and Methods}

\section{Participants}

The research involved a cohort of 302 PE-FTs, 202 $(66.9 \%)$ males and $100(33.1 \%)$ females, from total 314 PE-STs studying in the Higher Institute of Sport and Physical Education (ISSEP) Tunis (there are only 3 ISSEP, in Tunisia each has their own teaching practice modality). twelve participants did not participate in the study. All participants in this study were volunteers. They were recruited from a single Higher Institute of Sport (Tunis). The group of participants consisted of the third year PE-FT. The ages of the participants varied from 21 to 23 years old and the mean age was $21.62(S D=0.67)$. Nearly half of the participants carried out their teaching practice in an urban high school $(\mathrm{N}=49,16.2 \%), 69.5 \%$ $(\mathrm{N}=210)$ in a semi-urban high school and $14.2 \%(\mathrm{~N}=$ 43 ) in a rural setting. More than half of the participants ( $N$ $=187,61.9 \%$ ) did not have any further contact with the work world, while $38.1 \%(\mathrm{~N}=115)$ had some previous professional experience, mainly in education (teaching, training) and hotel sector. That experience was part-time. They were registered in an introductory practicum to professional training in Tunisia (introductory practicum applied to pedagogy), that is ended, in the last year, by the Fundamental License of Physical Education [13]. This activity has serves as an introduction to professional life. The activity lasts two semesters: four hours per week on Tuesday or Thursday for a cumulative total time of 116 hours of teaching $[30,31]$. Participants are not paid to participate in the research. They were not informed about the purpose and conception of the research.

\section{Measures}

This quantitative study explored the PE-STs appreciations regarding the supervision of their teaching practice. The first goal consists of portraying the trainees' overall perceptions about the advice provided by CT; their appreciations levels about theoretical and practical knowledge advice supplied, as well as the most negative aspects of their supervision process. The second goal comprises identifying the impact of the cooperative teacher's knowledge on attractiveness of student teachers. We used the questionnaire consisting of two dimensions in which we have grouped the different types of questions to clarify and give PE-STs the opportunity to share their preoccupation such as CT knowledge impact.

Data were collected through the questionnaire adapted from Inventory of Experiences and Perceptions at Teaching Practice, designed by Caires \& Almeida [32], consisting of 20 items: according to a 4-point Likert-type scale ranging from 4 from 1 (never) to 4 (usually) that were tested in a pilot study. The questionnaire includes 3 subscales which describe the training device in teaching practice on three different aspects: (i) The theoretical knowledge (evaluates trainees' perceptions of the referring to EP objectives and programs, pedagogical advice, choice situations, student evaluation, analysis Based on theoretical approaches); (ii) The practical knowledge (evaluates trainees' perceptions of the CT conscious of success and failure points, how to communicate and motivate students, transmits experience in sports training, false and transmits general knowledge); (iii) Attractiveness of the profession (evaluates the impact of the CT Knowledge on future-teachers' professional orientation, stopping work, the feeling of strong anger, the urge to cry). We have grouped the different types of questions to clarify and give PE-FTs the opportunity to share their preoccupation such as CT knowledge and attractiveness impact. Following the quantitative responses obtained from the questionnaire, we analyzed these data using the statistical software SPSS 16 (Statistical Package for social science).

\section{Procedures}

First of all, the permission was granted by the Director of ISSEP Tunis and teachers to realize the current study. Then, the researcher collected the PE-STs, explained the stages of the study and the different questions in the questionnaire for PE-STs, oversaw the privacy and uniqueness of answers. In this study, we presented to the PE-STs the different steps of this research to know the phases of the questionnaire. PE-STs were not informed of the purpose and design of the research. PE-STs are questioned by allowing them the freedom to respond, they can express themselves at their ease. Our data was analyzed using a statistic constant.

\section{Statistical Analysis}

Analyses were performed using statistical software SPSS 16 (Statistical Package for social science) program. The following variables were calculated using descriptive statistic: frequencies, percentages, and Cranach alpha index. Assessment of statistical significance between male and female student teachers was performed using a Chi-square. Correlation between CT's knowledge and attractiveness of PE-ST was applied. A p value less than 0.05 was considered statistically significant. 


\section{Results}

\section{The CT knowledge}

The theoretical knowledge (TK)

Eight items emerged from the data collected and were illustrated in Table 1: Item 1) CT proposes PE-ST to refer to the EP objectives, Item 2) CT proposes PEST to refer to the official programs, Item 3) CT transmits advice on the pedagogical aspect, Item 4) CT transmits PE-ST students mastery advice, Item 5) CT transmits PEST student security advice, Item 6) CT transmits PE-ST advice of choice situations, Item 7) CT talk about student evaluation, Item 8) CT's analysis based on theoretical approaches.

The "CT theoretical knowledge" includes eight items: Item 1: "CT proposes PE-ST to refer to the EP objectives" (Sometimes /Usually $=27.8 / 15.2 \%$ ); Item 2: "CT proposes PE-ST to refer to the official programs" ( $\mathrm{S} / \mathrm{U}=27.5 / 31.8 \%)$; Item 3: "CT transmits advice on the pedagogical aspect " ( $\mathrm{S} / \mathrm{U}=34.1 / 46.4 \%)$; Item 4: "CT transmits PE-ST students mastery advice” ( $\mathrm{S} / \mathrm{U}=34.4$ /38.4\%); Item 5: "CT transmits PE-ST student security advice" ( $\mathrm{S} / \mathrm{U}=32.5 / 43.4 \%)$; Item 6: "CT transmits PE-ST advice of choice situations" ( $\mathrm{S} / \mathrm{U}=40.4 / 25.8 \%)$; Item 7: "CT talk about student evaluation" ( $\mathrm{S} / \mathrm{U}=34.8 / 19.5 \%)$; Item 8: "CT's analysis based on theoretical approaches" $(\mathrm{S} / \mathrm{U}=29.8 / 15.6 \%)$
Significant gender differences were also found for $C T$ transmits PE-ST pedagogical advice $\left(\mathrm{X}^{2}=0.010\right.$, $P=11.409$; females stronger), CT analysis Based on theoretical approaches $\left(\mathrm{X}^{2}=0.000, P=19.928\right)$. No significant gender differences were found for $C T$ proposes $P E-S T$ to refer to the EP objectives $\left(\mathrm{X}^{2}=0.132, P=5.606\right)$, $C T$ proposes $P E-S T$ to refer to the official programs $\left(\mathrm{X}^{2}=\right.$ 0.504, $P=2.345)$, CT transmits PE-ST students' mastery advice $\left(\mathrm{X}^{2}=0.866, P=0.729\right), C T$ transmits $P E-S T$ security advice $\left(\mathrm{X}^{2}=0.094, P=6.392\right) . C T$ transmits advice of choice situations $\left(\mathrm{X}^{2}=0.416, P=2.844\right) . C T$ talks about student evaluation $\left(\mathrm{X}^{2}=0.671, P=1.548\right)$.

The practical knowledge $(\mathrm{PK})$

Eight items emerged from the data collected and were illustrated in Table 2: Item 1) CT conscious of PE-ST success and failure points, Item 2) CT impose these ideas to PE-ST, Item3) CT learns PE-ST how to communicate with students, Item 4) CT learns PE-ST how to motivate students, item 5) CT transmits his experience in sport training, Item 6) CT compare his experience to PE-ST, Item 7) CT false PE-ST knowledge, Item 8) CT Transmits general knowledge.

The "CT practical knowledge" includes eight items: Item 1: "CT conscious of PE-ST success and failure points" ( $\mathrm{S} / \mathrm{U}=36.8 / 36.8 \%)$; Item 2: "CT impose these ideas to PE-ST " $(\mathrm{S} / \mathrm{U}=30.5 / 36.8 \%)$; Item 3: "CT learns

Table 1. The different items of the CT theoretical knowledge

\begin{tabular}{lllllll}
\hline Items & $\begin{array}{l}\text { Never } \\
\text { (\%) }\end{array}$ & $\begin{array}{l}\text { Rarely } \\
\text { (\%) }\end{array}$ & $\begin{array}{l}\text { Sometimes } \\
\text { (\%) }\end{array}$ & $\begin{array}{l}\text { Usually } \\
\text { (\%) }\end{array}$ & $\mathbf{X}^{\mathbf{2}}$ & P \\
\hline $\begin{array}{l}\text { 1. CT proposes PE-ST to refer to the EP } \\
\text { objectives }\end{array}$ & 30.5 & 26.5 & 27.8 & 15.2 & 0.132 & 5.606 \\
$\begin{array}{l}\text { 2. CT proposes PE-ST to refer to the official } \\
\text { programs }\end{array}$ & 23.8 & 16.9 & 27.5 & 31.8 & 0.504 & 2.345 \\
3. CT transmits PE-ST pedagogical advice & 6.6 & 12.9 & 34.1 & 46.4 & 0.010 & 11.409 \\
4. CT transmits PE-ST students mastery advice & 13.6 & 14.6 & 33.4 & 38.4 & 0.866 & 0.729 \\
5. CT transmits PE-ST security advice & 7.3 & 16.9 & 32.5 & 43.4 & 0.094 & 6.392 \\
6. CT transmits advice of choice situations & 10.3 & 23.5 & 40.4 & 25.8 & 0.416 & 2.844 \\
7. CT talk about student evaluation & 16.2 & 29.5 & 34.8 & 19.5 & 0.671 & 1.548 \\
8. CT analysis Based on theoretical approaches & 28.1 & 26.5 & 29.8 & & 0.000 & 19.928 \\
\hline
\end{tabular}

Table 2. The different items of the CT practical knowledge

\begin{tabular}{|c|c|c|c|c|c|c|}
\hline Items & $\begin{array}{l}\text { Never } \\
(\%)\end{array}$ & $\begin{array}{l}\text { Rarely } \\
(\%)\end{array}$ & $\begin{array}{l}\text { Sometimes } \\
(\%)\end{array}$ & $\begin{array}{l}\text { Usually } \\
(\%)\end{array}$ & $\mathbf{X}^{2}$ & $\mathbf{P}$ \\
\hline $\begin{array}{l}\text { 1. CT conscious of PE-ST success and failure } \\
\text { points }\end{array}$ & 10.3 & 16.2 & 36.8 & 36.8 & 0.304 & 3.635 \\
\hline 2. CT impose his ideas to PE-ST & 12.9 & 19.9 & 30.5 & 36.8 & 0.587 & 1.932 \\
\hline $\begin{array}{l}\text { 3. CT learn PE-ST how to communicate with } \\
\text { students }\end{array}$ & 17.5 & 22.5 & 33.4 & 26.5 & 0.374 & 3.118 \\
\hline 4. CT learn PE-ST how to motivate students & 11.6 & 21.9 & 38.1 & 28.5 & 0.331 & 3.422 \\
\hline $\begin{array}{l}\text { 5. CT transmits to PE-ST his experience in sports } \\
\text { training }\end{array}$ & 40.7 & 28.8 & 16.9 & 13.6 & 0.110 & 6.023 \\
\hline 6. CT compare his experience to PE-ST & 36.1 & 26.5 & 22.8 & 14.6 & 0.038 & 8.422 \\
\hline 7. CT false PE-ST knowledge & 34.1 & 27.2 & 26.8 & 11.9 & 0.014 & 10.677 \\
\hline 8. CT transmits PE-ST general knowledge & 9.6 & 21.2 & 44.7 & 24.5 & 0.978 & 0.197 \\
\hline
\end{tabular}


PE-ST how to communicate with students" ( $\mathrm{S} / \mathrm{U}=33.4$ 126.5\%); Item 4: "CT learns PE-ST how to motivate students " ( $\mathrm{S} / \mathrm{U}=38.1 / 28.5 \%)$; item 5: "CT transmits his experience in sports training" ( $\mathrm{S} / \mathrm{U}=16.9 / 13.3 \%)$; Item 6: "CT compare his experience to PE-ST" ( $\mathrm{S} / \mathrm{U}=22.8$ /14.6\%); Item 7: "CTfalse PE-ST knowledge” ( $\mathrm{S} / \mathrm{U}=26.8$ /11.9\%); Item 8: "CT Transmits general knowledge” (S/U $=44.7 / 24.5 \%$ ).

Significant gender differences were also found for $C T$ compare his experience to PE-ST $\left(\mathrm{X}^{2}=0.032, P=\right.$ 8.422.; females stronger), CT false PE-ST knowledge ( $\mathrm{X}^{2}$ $=0.014, P=19.928$ ). No significant gender differences were found for CT conscious of PE-ST success and failure points $\left(\mathrm{X}^{2}=0.304, P=3.635\right)$, impose his ideas to $P E-S T$ $\left(\mathrm{X}^{2}=0.587, P=1.932\right)$, learn PE-ST how to communicate with students $\left(\mathrm{X}^{2}=0.374, P=3.118\right)$, how to motivate students $\left(\mathrm{X}^{2}=0.331, P=3.422\right)$. CT transmits to PE-ST his experience in sports training $\left(\mathrm{X}^{2}=0.110, P=6.023\right)$ and general knowledge $\left(\mathrm{X}^{2}=0.978, P=0.197\right)$.

Impact on attractiveness of the profession (AP)

Four items were identified from the data collected and illustrated in Table 3: item 1) Having considered another professional orientation, item 2) Having considered a work stoppage, item 3) The feeling of strong anger, the urge to cry, item 4) Having thought to be in a bad situation.

The "The attractiveness of the profession repercussions" of PE-ST from CT includes five items: Item 1: "Consider another professional orientation" ( $\mathrm{S} / \mathrm{U}=13.9$ /8.6\%); Item 2: "Having considered a work stoppage" ( $\mathrm{S} / \mathrm{U}=15.9$ $14.6 \%)$; Item 3: "The feeling of strong anger, the urge to cry" ( $\mathrm{S} / \mathrm{U}=32.1 / 14.6 \%)$; Item 4: "Having thought to be in a bad situation" ( $\mathrm{S} / \mathrm{U}=32.5 / 13.9 \%)$.

Significant gender differences were also found for $P E$ $S T$ feeling of strong anger, the urge to cry $\left(\mathrm{X}^{2}=0.000\right.$, $P=22.000$; females stronger). No significant gender differences were found for PE-ST Consider another professional orientation $\left(\mathrm{X}^{2}=0.866, P=0.732\right)$, having considered a work stoppage $\left(\mathrm{X}^{2}=0.227, P=4.339\right), C T$ remains in the classroom $\left(\mathrm{X}^{2}=0.501, P=2.362\right)$, having thought to be in a bad situation $\left(\mathrm{X}^{2}=0.909, P=0.544\right)$.

Table 4 shows that the correlations supported the positive, significant relationship between all the CT theoretical knowledge and the attractiveness of the profession. However, having "considered another professional orientation" was only significantly associated with "CT transmits PE-ST security advice" $(\mathrm{r}=0.031 ; p=0.108)$, "CT analysis Based on theoretical approaches" ( $\mathrm{r}=0.020 ; p=0.118)$. "Consider stopping work in an internship" was only significantly associated with "CT transmits PE-ST masters students advice" $(\mathrm{r}=0.030 ; p=0.108)$ and "CT analysis Based on theoretical approaches" $(\mathrm{r}=0.016 ; p=0.124)$.

The results on Table 5 indicate that the correlations supported the positive, significant relationship between all the CT practical knowledge and the attractiveness of the profession. However, having "considered another professional orientation" was only significantly associated with "CT transmits to PE-ST his experience in sports training" ( $\mathrm{r}=0.020 ; p=0.118)$. "Consider stopping work in an internship" was only significantly associated with

Table 3. The attractiveness of the profession

\begin{tabular}{|c|c|c|c|c|c|c|}
\hline Items & $\begin{array}{l}\text { Never } \\
(\%)\end{array}$ & $\begin{array}{l}\text { Rarely } \\
(\%)\end{array}$ & $\begin{array}{l}\text { Sometimes } \\
(\%)\end{array}$ & $\begin{array}{l}\text { Usually } \\
\text { (\%) }\end{array}$ & $\mathbf{X}^{2}$ & $\mathbf{P}$ \\
\hline 1. Consider another professional orientation & 54.6 & 22.8 & 13.9 & 8.6 & 0.866 & 0.732 \\
\hline 2. Consider stopping work in an internship & 58.9 & 20.5 & 15.9 & 4.6 & 0.227 & 4.339 \\
\hline 3. Have the feeling of strong anger, the urge to cry & 31.1 & 22.2 & 32.1 & 14.6 & 0.000 & 22.00 \\
\hline $\begin{array}{l}\text { 4. Have thought to be in a bad situation at the } \\
\text { internship }\end{array}$ & 23.2 & 30.5 & 32.5 & 13.9 & 0.909 & 0.544 \\
\hline
\end{tabular}

Table 4. Correlations between the $\mathrm{CT}$ theoretical knowledge and the PE-ST attractiveness

\begin{tabular}{|c|c|c|c|c|c|c|c|c|c|}
\hline Items & Correlation & TK1 & TK2 & TK3 & TK4 & TK5 & TK6 & TK7 & TK8 \\
\hline & Pearson Correlation & .036 & .043 & .048 & .005 & $.108^{*}$ & -.020 & -.036 & $.118^{*}$ \\
\hline \multirow[t]{3}{*}{ AP 1} & Sig. (1-tailed) & .266 & .227 & .201 & .463 & .031 & .362 & .265 & .020 \\
\hline & $\mathrm{N}$ & 302 & 302 & 302 & 302 & 302 & 302 & 302 & 302 \\
\hline & Pearson Correlation & .043 & .046 & .015 & $.108^{*}$ & .024 & .009 & -.016 & $.124^{*}$ \\
\hline \multirow[t]{3}{*}{ AP 2} & Sig. (1-tailed) & .229 & .212 & .400 & .030 & .339 & .435 & .392 & .016 \\
\hline & $\mathrm{N}$ & 302 & 302 & 302 & 302 & 302 & 302 & 302 & 302 \\
\hline & Pearson Correlation & .043 & -.019 & -.074 & .088 & -.003 & -.038 & .008 & -.042 \\
\hline \multirow[t]{3}{*}{ AP 3} & Sig. (1-tailed) & .226 & .369 & 100 & .065 & .481 & .254 & .444 & .233 \\
\hline & $\mathrm{N}$ & 302 & 302 & 302 & 302 & 302 & 302 & 302 & 302 \\
\hline & Pearson Correlation & -.010 & -.027 & -.043 & .070 & .006 & -.074 & -.084 & .054 \\
\hline \multirow[t]{2}{*}{ AP 4} & Sig. (1-tailed) & .431 & .320 & .228 & .112 & .459 & .100 & .073 & .175 \\
\hline & $\mathrm{N}$ & 302 & 302 & 302 & 302 & 302 & 302 & 302 & 302 \\
\hline
\end{tabular}

Note: ${ }^{* *}$. Correlation is significant at the 0.01 level (1-tailed). ${ }^{*}$. Correlation is significant at the 0.05 level (1-tailed). 
Table 5. Correlations between the CT practical knowledge and the PE-ST attractiveness

\begin{tabular}{|c|c|c|c|c|c|c|c|c|c|}
\hline Items & Correlation & PK1 & PK2 & PK3 & PK4 & PK5 & PK6 & PK7 & PK8 \\
\hline \multirow{3}{*}{ AP 1} & Pearson Correlation & -.075 & .025 & -.041 & .060 & .017 & $.118^{*}$ & .070 & .084 \\
\hline & Sig. (1-tailed) & .096 & .334 & .241 & .151 & .386 & .020 & .113 & .072 \\
\hline & $\mathrm{N}$ & 302 & 302 & 302 & 302 & 302 & 302 & 302 & 302 \\
\hline \multirow{3}{*}{ AP 2} & Pearson Correlation & -.083 & $.120^{*}$ & -.073 & .000 & .060 & $.124^{*}$ & $.113^{*}$ & $.129^{*}$ \\
\hline & Sig. (1-tailed) & .075 & .019 & .104 & .497 & .149 & .016 & .025 & .013 \\
\hline & $\mathrm{N}$ & 302 & 302 & 302 & 302 & 302 & 302 & 302 & 302 \\
\hline \multirow{3}{*}{ AP 3} & Pearson Correlation & -.077 & .085 & -.056 & -.006 & .038 & -.042 & $.237^{* *}$ & .091 \\
\hline & Sig. (1-tailed) & .090 & .071 & .167 & .457 & .253 & .233 & .000 & .056 \\
\hline & $\mathrm{N}$ & 302 & 302 & 302 & 302 & 302 & 302 & 302 & 302 \\
\hline \multirow{3}{*}{ AP 4} & Pearson Correlation & -.066 & .052 & -.052 & .012 & .039 & .054 & $.204^{* *}$ & .059 \\
\hline & Sig. (1-tailed) & .128 & .185 & .185 & .416 & .250 & .175 & .000 & .155 \\
\hline & $\mathrm{N}$ & 302 & 302 & 302 & 302 & 302 & 302 & 302 & 302 \\
\hline
\end{tabular}

Note: ${ }^{* *}$. Correlation is significant at the 0.01 level (1-tailed). *. Correlation is significant at the 0.05 level (1-tailed).

"CT impose his ideas to PE-ST" ( $\mathrm{r}=0.019 ; p=0.120)$, "CT compare his experience to PE-ST" ( $\mathrm{r}=0.016 ; p=0.124)$, "CT false PE-ST knowledge" ( $\mathrm{r}=0.025 ; p=0.113)$ and "CT's analysis Based on theoretical approaches" $(\mathrm{r}=0.013 ; p=0.129)$. "Have the feeling of strong anger, the urge to cry" was only significantly associated with "CT false PE-ST knowledge" ( $\mathrm{r}=0.000 ; p=0.237)$. "Have thought to be in a bad situation at the internship" was only significantly associated with "CT false PE-ST knowledge" ( $\mathrm{r}=0.000 ; p=0.204)$.

\section{Discussion}

Le role of $\mathrm{CT}$ is to provide a training quality in terms of teaching practice for student-trainees that meet the challenges and requirements of work environment as a whole, which have not been recognized. Thus, the purpose of this research was to identify CT knowledge problems (academic and experiential knowledge) and analyze the impact on attractiveness of student teachers (PESTs) which are believed to be important for a successful teaching and training device in the workplace.

According to our results, the workplace is the learning environment in which the trainee student is located and integrates the material device, the objects of knowledge or know-how, previous acquisitions and the memory of the class. In this context, the concept of didactic contract is central, concentrating the rules that organize the teacher / student / knowledge relationship. It is the anchor from which didactic observation can be structured [33]. As part of the training contract, Carlier [16] suggests clarifying the mutual expectations between PE-ST and CT according to the internship objectives. The CT must take the initiative of establishing the contract: "Me, Cooperative Teacher, what are my strengths, my specificities? What can I honestly and modestly bring to you, which you will not find elsewhere? " [14]. According to Darnis \& Magendie [34], CT adopts an investigative posture and leads the trainee to use his theoretical knowledge, to mobilize them, to confront them with obstacles encountered in the field. In order to properly guide the verbalization of his action, Carlier [14] suggests that the CT establish a trusting relationship and a communication contract with PE-ST. He notices CT enters the trainee's intimacy through questioning. From his first contact with trainees, Mouton [35] notes that the organization and conduct of the internship that sets up EA will influence the effectiveness of advice and their appropriations.

Our results, Also, showed knowledge problems between CT and PE-ST. Crinon [36] suggests not to lead PE-ST to mourn his practice, rather to lead him to rethink and deepen the meaning through a reflexive return on the discipline and its meaning: by asking what it means to do physical education (PE) with this class? One must ask: How, despite everything, make them do PE?

According to Schon [37] the paradigm that has dominated the research is the reflexive teacher. Moreover, the valued training practices are those that promote reflexivity. In this sense, Paquay [38] asks a question: what strategies to train reflexive practitioners? In these studies, he discovered that the means of training reflexive teachers are multiple: first of all, to carry out a situational diagnosis. Then, produce instrumental approaches to teaching in reference to a theory. Finally, prepare lessons by explaining the choices and associate PE-ST to evaluate their courses. In addition, He noted that the critical point of a formation of "reflexive teacher" is the accompaniment by experienced CT who are accustomed to think of their practices. Concretely, if the internships are prepared, supervised and exploited. They can contribute to the professionalization of reflexive teachers.

Dugal \& Amade-Escot [39], also, described each CT attitudes in these interactions. He noticed that the CT adopted three dominant attitudes in these postlesson interviews: attitudes of investigation, evaluation and decision-making. However, Tannehill \& Zakrajsek [40] noticed that the communication structure during the meetings between the CT and PE-ST was organized around suggestions for the improvement of the PE-ST practice rather than around a dynamic that encourages reflection. Also, they stated that CTs meet PE-STs once 
a week in a formal way (scheduled meeting to talk about ES intervention).

Dugal \& Amade-Escot [39] found that attitudes of understanding, support and interpretation were less observed. They advanced as interpretation that the frequently attitudes observed in the post-lesson interviews referred to attitudes about their role as teachers of PE, which led to confusion with the CT role. This interpretation is consistent with that proposed by Pelpel [41].

The discomfort, stress, distress and dropout professional in the workplace can be provided by CT knowledge. Our results demonstrate that the impact of CT knowledge problems and attractiveness was significant.

Paquay \& Wagner [42] found that the internship is an opportunity for PE-ST to conform to traditional practices, to discover recipes and to gain practical knowledge entirely cut off from theory. He argues that only a reflexive analysis would allow a transposition and an adaptation of this practical knowledge to new situations. Calderhead [43] state that insecure PE-ST cling to these "practical knowledge" to the point that they become hermetic to any theorizing.

In describing the forms of joint commitments and interactions, Trohel et al. [44] noticed that the CT is not trained in the role of tutor; they act according to their professional experience in teaching physical education. Darnis \& Magendrie [34] propose to train mentors in counselling skills so that they are able to encourage reflective analysis in ES and engage in an active search for solutions to problems encountered. Thus, The CT must secure and support the PE-ST, both materially and psychologically. Rajuan et al. [45] opined to introduce trainees to students and to give them as much information as possible about the program and materials.

In most countries, according to Paquay [46], the Thus, a professional is a person who performs intellectual acts autonomously and responsibly. The professional is autonomous since he is able to self-regulate and guide their action and learning through critical analysis of the results of his practice. Wideen [47] defines the teacher as a strategist who updates his basic knowledge and tries a new approach to improve the efficiency of his practice. Perrenoud [48] state that this is the ability to capitalize on the experience and reflect on its practice to reorganize teaching profession tends to be considered a profession.

it. The practitioner according to Tardif [49] constitutes an experiential knowledge in evolution. Paquay [38] found that the theoretical and pedagogical skills are acquired through long training.

\section{Conclusion}

This article focuses on the role of supervisory knowledge in the professional development of future teachers. In addition, it describes a teacher development monitoring framework, reflect on teaching practices, and reflection on a more integrated knowledge of theory and practice of the teaching profession. The questions addressed in this study will encourage CT to reflect on their own knowledge, training device and to include them in the process of accompaniment of PE-STs. Our results reflect the views of all the population of PE-ST exercising their traineeship in schools of Tunis. In light of our results, it is possible to make a statement concerning CT teaching practice and share PE-ST preoccupation such as knowledge impact. We are far from an ideal accompaniment situation and PE-ST problems that life must draw the attention of the priority of the internship responsible. Furthermore, the hypothesis is verified: $\mathrm{CT}$ teaching practice can be characterized by a high variability, namely knowledge on a scale Frequency converter.

According to some of the literature, $\mathrm{CT}$ was a person of alternation between academia and training, a key element on the student teachers' emotional balance and support for teaching at time of the teaching profession $[50,30,51]$. It is in the knowledge interchange setting that the student teachers seem to find more adequate answers emerging during the practice, helping him/her to overcome the confusion and discomfort, the feelings of incapability and doubt their practices [6, 52-54].

In Tunisia, we saw that teaching practices offer relatively favorable climate training. This statement should hold the attention of $\mathrm{CT}$, supervisors, university teachers and people in charge of training, and get them to think a light of PE-STs preoccupation. So, teaching practices are calling for new developments in the near future. Data from PE-STs provide lighting and additional lines of investigation to improve teaching practices.

\section{Conflict of interest}

The authors declare no conflict of interest.

https://doi.org/10.1108/HESWBL-04-2016-0022

1. Altet M. The competences of the teacher-professional: between knowledge, action and adaptation schemes, knowledge analysis. Education and training opportunities, 2012; 4, 43-57.

2. Pennaforte AP. Organizational supports and individual's commitments through work integrated learning. Higher Education, Skills andWork-Based Learning, 2016;6(1):89-99. https://doi.org/10.1108/HESWBL-07-2015-0038

3. Perera S, Babatunde SO, Pearson J, Ekundayo D. Professional competency-based analysis of continuing tensions between education and training in higher education. Higher Education, Skills and Work-Based Learning, 2017; 7(1): 92-111.
4. Masciotra D. Constructivism in simple terms. Educational life, 2007; 143, 48-52.

5. Den Brok PJ, Wubbels T, van Tartwijk JWF. Exploring beginning teachers' attrition in the Netherlands. Teachers and teaching, 2017; 23(8): 881- 895. https://doi.org/10.1080/13540602.2017.1360859

6. Bali N, Zayed W, Hassen Z, Hermassi S, Chtara M, Mrayah M, et al. The Conceptions of Integration of Tunisian Physical Education Cooperative Teachers and Student Teachers. Creative Education, 2014;05:279-89. https://doi.org/10.4236/ce.2014.54037

7. Tardif J. The influences of cognitive psychology on teaching 
and evaluation practices. Quebec Journal of Psychology, 1995; 16(2), 175-207.

8. Schmidt M, Knowles JG. Four Women's Stories of Failure as Beginning Teachers. Paper presented at the AERA conference, 4-10. ED 375 080. New Orleans; 1994.

9. Brawdy P, Byra M. Supervision of Preservice Teachers during an Early Field Teaching Experience. Physical Educator, 1995; 52(3): 147-59.

10.Munby H, Russell T, Martin AK. Teachers' Knowledge and How It Develops. In V. Richardson (4e ed.), Handbook of Research on Teaching, Washington, D.C.: American Educational Research Association; 2001. P. 877-904.

11.Desbiens JF, Borges C, Spallanzani C. Educational supervision in physical education. Education and Francophone, 2009; 37: 1- 5. https://doi.org/10.7202/037649ar

12.Perez-Roux T. Identity Construction of New Teachers: What Recognition of Others to (Re) Known as a Professional?. Educations \& Research Journal, 2012; 7: 69-84.

13.Zayed W, Bali N, Souissi N, Desbiens JF. The Conception of Tunisian Student Teachers of the Formative Role of the Cooperative Teacher's. Creative Education, 2015; 6(10): 1060- 1075. https://doi.org/10.4236/ce.2015.610105

14.Carlier G. Supervise trainees in physical education: guidelines for a function in the process of professionalization. Catholic University of Louvain. Belgium; 2002.

15.Boutet M, Rousseau N. The challenges of pedagogical supervision of internships. Québec: PUQ; 2002.

16.Carlier G. Supervise trainees in physical education: beacons for a function in the process of professionalization. PhenEPS Review / PHEnex Journal, 2009; 8: 96-111.

17.Desbiens JF. Field experience in Canadian initial teacher education. Handbook of Canadian Research in Initial Teacher Education; 2015.

18. Vandercleyen F, Delens C, Carlier G. Supervisory styles of training supervisors in physical education: taking into account the emotional experience of trainees during a postlesson interview. EJRIEPS; 2013.

19.Chaliès S, Durand, M. Summary note the usefulness of tutoring in initial teacher training: Forms and devices of professionalization. Research and Training, 2000, 35(1): 145-180

20.Lebel C, Bélair LM. The factors of perseverance in teaching. In: Actes colloque de l'AREF [News from research and training], France: University of Strasbourg; 2007.

21.Doudin PA, Curchod-Ruedi D, Lafortune L, Lafranchise N. The psychosocial health of teachers. Québec: Presses of the University of Québec; 2011.

22.Bali N, Zayed W, Hassen Z, Hermassi S, Chtara M, Mrayah M, Desbiens JF. The Conceptions of Integration of Tunisian Physical Education Cooperative Teachers and Student Teachers. Creative Education, 2014; 5(04), 279- 289. https://doi.org/10.4236/ce.2014.54037

23.Desbiens JF, Borges C, Spallanzani C. I harm to my internship: problems and issues of practical training in teaching. Québec: PUQ; 2012.

24.Zayed W, Souissi N, Bali N. The professional inclusion dimension in teaching practice: an inventory of experiences and perceptions of Tunisian Future-Teachers. Transylvanian Review, 2018a; 1(1).

25.Ndoreraho JP, Martineau S. A problem of early career in teaching. Retrieved November; 2006.

26.Brau-Antony S, Mieusset C, Lenfant A, Miot, C. Analyze the work of tutors of beginning teachers. Permanent Education,
2011; 186: 175-185.

27.Faingold N. Training of trainers in the analysis of practices. Research and Training, 2006; 51: 89-10.

28.Perez-Roux T. Professional insertion of teachers and identity construction at the test of the profession. Review of the HEP of French-speaking Switzerland and Ticino, 2016; 21: 95115.

29.Bali N. The Tunisians Cooperative Teachers and Student Teachers' Conceptions about Class Management Skill. Creative Education, 2015;06:87-99 https://doi.org/10.4236/ce.2015.61008

30.Zayed W, Bali N. Introduction of student teachers in Tunisian secondary schools: A discourse analysis of cooperative teacher. Creative Education, 2015; 6(3): 359- 368. https://doi.org/10.4236/ce.2015.63034

31.Bali N. The No-Participation of Students in Physical Education: A Comparative Study of Tunisian Trainee Teachers. Creative Education, 2016;07:1486-99. https://doi.org/10.4236/ce.2016.710154

32. Caires S, Almeida LS. Positive aspects of the teacher training supervision: The student teachers' perspective. European Journal of Psychology of Education 2007;22:515-28. https://doi.org/10.1007/BF03173469

33.Amade-Escot C. Interactive management of didactic contract in volleyball. In: C. Amade-Escot (ed.), Didactics of physical education; research status. Paris: EPS Review; 2003. P. 255278.

34.Darnis F, Magendie E. Alternate teacher training: towards the co-construction of pragmatic concepts. Review Knowledge, 2011; 27: 63-83.

35.Mouton JC. Analysis of the consulting activity of the master trainer in practice. Research and Training, 2009; 62: 65-76.

36.Crinon J. The professional memory of teacher's observatory practices and leverage for training. France: Harmattan; 2003.

37. Schon DA. Educating the Reflective Practitioner: Toward a New Design for Teaching and Learning in the Professions. San Francisco: Jossey-Bass; 1987.

38.Paquay L. Continuity and progress in research on teacher training. In: Train professional teachers. France: Superior Boeck; 2012. P. 5-26.

39.Dugal J-P, Amade-Escot C. Training in consulting and professional development of educational consultants. Research and Training, 2004; 46: 97-116.

40.Tannehill D, Zakrajsek D. What's happening in supervision of student teachers in secondary physical education?. Journal of Teaching in Physical Education, 1988; 8(1):1-12. https://doi.org/10.1123/jtpe.8.1.1

41.Pelpel P. What professionalization for field trainers?. In: Teacher Trainers. France: Superior Boeck; 2002. P. 175-191.

42.Paquay L, Wagner MC. Preferred professional skills in internships and video-training. In: Paquet L, Alter $\mathrm{M}$, Charlier E \& Ph. Perrenoud ( $3^{\mathrm{e}}$ Ed.), Train professional teachers. What strategies? What skills? Bruxelles: Editions de Boeck University; 2001. P. 153-179.

43.Calderhead J. Conceptualization and evaluation of the professional training of teachers. Research and training, 1992; 11: 51-63.

44.Trohel J, Chalies S, Saury J. The dynamics of trainee-trainee interactions in situation of educational advice. Knowledge, 2004; 2: 119-140.

45.Rajuan M, Beijaard D, Verloop N. The role of the cooperating teacher: Bridging the gap between the expectations of cooperating teachers and student teachers. Mentoring \& tutoring, 2007; 15(3): 223-242. 
https://doi.org/10.1080/13611260701201703

46.Paquay L. To a repository of teacher's professional skills?. Research \& Training, 1994; 16 (1): 7-38.

47.Wideen M. Become a teacher, what does that mean? In: Holborn P, Wideen M et Andrews L, Become a teacher, Montréal: Logic Edition; 1992. P. 25-37.

48.Perrenoud P. Teacher training: between theory and practice. Paris: L'Harmattan; 1994.

49.Tardif J. The assessment of skills. Document the development path. Montreal: Chenelière Éducation; 2006.

50.Caires S, Almeida L, Vieira D. Becoming a teacher: Student teachers' experiences and perceptions about teaching practice. European Journal of Teacher Education, 2012; 35: 163-178. https://doi.org/10.1080/02619768.2011.643395
51.Sheridan L, Young M. Genuine conversation: the enabler in good mentoring of pre-service teachers. Teachers and Teaching, 2017; 23(6): 658-673. https://doi.org/10.1080/13540602.2016.1218327

52.Kosnik C. It is not just practice: Conflicting goals, unclear expectations. In: F.J, Benson \& C. Riches (ed.), Engaging in Conversations about ideas in Teacher Education. New York: Falmer Press; 2009. P. 65-71.

53.Gilbert MC, Education EPE. An attempt at understanding the psychological suffering of teachers: a psycho-dynamic reading of work. Québec: University Laval; 2012.

54.Smith K, Ulvik M. Leaving teaching: lack of resilience or sign of agency?. Teachers and Teaching, 2017; 23(8): 928-945. https://doi.org/10.1080/13540602.2017.1358706

\section{Information about the authors:}

Zayed W.; (Corresponding author); http://orcid.org/0000-0001-9334-6964; zayed-wadii@hotmail.com; Higher Institute of Sport and Physical Education; Road of Tozeur 2100, Gafsa Tunisia.

Zguira M.S.; http://orcid.org/0000-0002-6057-6197; sami-zguira@hotmail.fr; Higher Institute of Sport and Physical Education; Road of Tozeur 2100, Gafsa Tunisia.

Souissi N.; http:// orcid.org/0000-0003-1129-6727; n.souissi@yahoo.fr ; Higher Institute of Sport and Physical Education; Ksar Saïd 2010, MANOUBA Tunisia.

Bali N.; http://orcid.org/0000-0001-7751-6273; naila_bali@yahoo.fr; Higher Institute of Sport and Physical Education; Ksar Saïd 2010, MANOUBA Tunisia.

Cite this article as:

Zayed W, Zguira MS, Souissi N, Bali N. The determination of cooperative teacher's knowledge problems: training device and attractiveness of Tunisian student-teachers. Physical education of students, 2019;23(2):98-105.

https://doi.org/10.15561/20755279.2019.0208

The electronic version of this article is the complete one and can be found online at:

https://sportedu.org.ua/index.php/PES/issue/archive

This is an Open Access article distributed under the terms of the Creative Commons Attribution License, which permits unrestricted use, distribution, and reproduction in any medium, provided the original work is properly cited http://creativecommons.org/licenses/by/4.0/deed.en

Received: 10.03.2019

Accepted: 12.04.2019; Published: 28.04.2019 